\title{
Utilization of Coffee Husks to Prepare Functional Products
}

\author{
Mohamed F. Serag El-Din ${ }^{1 *}$ and Hayam A. Elsawy ${ }^{2}$ \\ ${ }^{1}$ Department of Nutrition and Food Sciences, Faculty of Home Economics, Menofia University, Shebin El-Kom, Egypt. \\ ${ }^{2}$ Department of Special Food and Nutrition, Food Technology Research Institute, Agricultural Research Center, \\ Ministry of Agriculture Land Reclamation, Giza, Egypt.
}

Received: $7 / 9 / 2021$

\begin{abstract}
Coffee husks are a by-product resulting from dehulling the coffee cherries during dry processing. Our study aimed to investigate the effect of coffee husks on hyperlipidemic rats and utilization it to prepare the balady bread loaves as a function product. For this purpose, 25 albino rats were divided to 5 subgroups and fed on a high fat diet with different levels of coffee husks. After two months, the lipid profile showed a reduction in total cholesterol, LDL-C, VLDL-C, and an increase in HDL-C which recorded 117.41, 24.46, and $47.46 \mathrm{mg} / \mathrm{dl}$ respectively, at $15 \%$ coffee husks replacement. Balady bread was prepared by wheat flour ( $82 \%$ extraction rate) with $5,10,15$, and $20 \%$ coffee husks level. The bread was evaluated by 15 panelists for sensory evaluation. All samples were acceptable and good except 20 $\%$ coffee husks. These results were confirmed by analyzing the texture of the bread in the lab. In addition, the paper valued the coffee husks as antioxidant source as showed by different antioxidant activity assays (DPPH, ABTS, and FRAB). The DPPH, ABTS, and FRAP were 207.254, 2.054, and 0.832 g Trolox/g sample, respectively. Generally, the coffee husks have a potential effect in improving lipid profile of hyperlipidemic rats and a good source for making a new functional food product.
\end{abstract}

Keywords: Coffee husks, Antioxidants, bread, phenolic acids

\section{INTRODUCTION}

Coffee is considered one of the most favorite beverages in the world. In 2020, the rate of global coffee consumption reached about 165 million bags contained à $60 \mathrm{~kg}$ of coffee, and Brazil is the largest producer in the world (ICO, 2020), this amount was approximately equal to 19.7 billion packages of coffee which were bought all over the world. Ethiopia is the main home of the coffee tree, and it is cultivated in over 80 countries worldwide (Murthy and Naidu, 2012a). The coffee tree is a perennial tree that takes 3-4 years to start blooming, and it produces the maximum yield after 10-15 years (Berlitz et al., 2009). After harvesting, coffee cherries can be subjected to dry or wet processing methods to obtain green coffee beans which constitute only $50-55 \%$ of the dry matter of the ripe cherry. Coffee husks are the fibrous mucilaginous by-product resulting from dehulling the coffee cherries during dry processing (Bekalo and Reinhardt, 2010; Castaldo et al., 2018). The burning or disposal of coffee husks without any safe treatment causes environmental problems, especially in the producing countries (Rebollo-Hernanz et al., 2021). For many years, coffee husks using to prepare a traditional beverage "Cascara beverage" that consume in Yemen and Ethiopia (Heeger et al., 2017). But recently, many studies have been carried out to use coffee husks in other fields such as silage, aerobic composting, animal feed, vermiculture, production of biogas, vinegar, biopesticides, enzymes, single-cell protein, probiotics, food industries, and pharmaceutical industries because it contains high levels of caffeine, bioactive compounds with antioxidant activity, and dietary fiber (Mennini, 2013; Rebollo-Hernanz et al., 2021). The coffee husks contains three important compounds that affect the body (Hoseini et al., 2021): Caffeine increases weight loss by encouraging heat production and lipid peroxidation in the body, diterpenes exert anti- inflammatory effects (Bidel and Tuomilehto 2013; Meng et al., 2013), and chlorogenic acid impact glucose metabolism by preventing hepatic glucose-6phosphatase activity and inhibition of glucose absorption in the small intestine by preventing glucose6-phosphate translocase 1 as well (Naveed et al., 2018). For many years, many studies carried out to investigate the relationship between obesity and caffeine. Obesity is a global problem in adults and children worldwide. The World Health Organization (WHO) indicates that overweight and obesity cause more people die than underweight (Pan et al., 2016). In 2016 , more than 1.9 billion adults, 18 years and older, were overweight. Of these over 650 million were obese (WHO, 2020). Obesity is related to the risks of many diseases such as hypertension, heart diseases, type 2 diabetes, some types of cancer, and non-alcoholic fatty liver disease (Lee et al., 2017). The objective of this study was using coffee husks in improving lipid profile of hyperlipidemic rats and manufacturing a good functional product fortified by different levels of coffee husks.

\section{MATERIALS AND METHODS}

\section{Sample collection}

The Coffee husks was obtained from the dry coffee roaster (coffee roaster STA - Italy) in Shebin ElKom, Menofia Governorate, Egypt. The coffee husks were cleaned and carefully sieved to remove foreign materials. After that, the coffee husks were ground by an electric mill (Retsch mill, 5657 HAAN, Germany) and passed through 80 mesh sieves (British standard screen). The fine powder was kept in glass containers and stored at $-20^{\circ} \mathrm{C}$ until used.

\section{Chemical composition}

Total ash, total protein, total fiber, and total lipids content of the dry coffee husks powder were determined as described by the AOAC (2000). 


\section{Identification of phenolic compounds by HPLC}

A known weight of the dried coffee husks was soaked in $25 \mathrm{ml}$ sterilized water and still on a shaker for $24 \mathrm{~h}$. The aqueous extract was filtered through Whatman $3 \mathrm{MM}$ filter paper under vacuum, followed by centrifugation at $10000 \mathrm{rpm}$ for $30 \mathrm{~min}$ at $80^{\circ} \mathrm{C}$. Phosphoric acid was used to acidify an aqueous extract to $\mathrm{pH}$ 2.5. Each sample was partitioned three times with an equal volume of diethyl ether. The layer of diethyl ether was evaporated to dryness under low pressure at $30^{\circ} \mathrm{C}$. The resulting residue was dissolved in $3 \mathrm{ml}$ of spectral grade methanol and filtered through a $0.2 \mathrm{~mm}$ Sterilized filter membrane prior to HPLC analysis. Identification of individual phenolic compounds of the coffee husks samples was performed on a Hewlett-Packard HPLC (Model 1100), using $\mathrm{C}_{18}$ reversed-phase column $(250 \times 4.6 \mathrm{~mm})$ with $5 \mathrm{~mm}$ particle size. A constant flow rate $(1 \mathrm{ml} / \mathrm{min})$ was used with two mobile phases. (A) $0.5 \%$ acetic acid in distilled water at $\mathrm{pH} 2.65$, and solvent (B) $0.5 \%$ acetic acid in $99.5 \%$ acetonitrile. The gradient of elution was starting with mobile phase A and ending with mobile phase B during $35 \mathrm{~min}$, using an UV detector set at wavelength $254 \mathrm{~nm}$. The relative retention times were used to identify the phenolic compounds in each sample comparing with standard mixture of phenolic compounds. Peak area measurements were used to calculate the concentration of each phenolic compound, then converted to $\mu \mathrm{g}$ phenolic acid/g dry weight.

\section{Antioxidant Capacity Assays}

\section{Sample preparation}

Ethanol extract of coffee husks was prepared as follows: $0.5 \mathrm{~g}$ of ground coffee husks was added to 50 $\mathrm{ml}$ ethanol. The mixture was left on a shaker for $24 \mathrm{~h}$, then centrifuged under cooling at $10000 \mathrm{rpm}$ for 10 min, and the supernatant was filtered through Whatman No. 41 filter paper. The volume of filtered supernatant was adjusted to $50 \mathrm{ml}$ again, kept at $-20^{\circ} \mathrm{C}$, and for up to one week to use .

\section{DPPH, ABTS, and FARP antioxidant activity assays}

Three activity assays were carried out to measure the free radical scavenging capacity of coffee husks ethanolic extract using the DPPH assay $(1,1-$ diphenyl-2-picryl hydrazyl) according to the method described by Akillioglu and Karakaya (2010), the ABTS $\bullet+$ assay was carried out according to the method of Gouveia and Castilho (2011) and FRAP assay was carried out according to the method reported by Benzie and Strain (1996).

\section{Preparation of balady bread.}

Balady bread preparation was done on an automatic commercial baking line according to Eissa et al. (2007) as in the official baking house, North of Cairo city, Egypt.

In the control sample, balady bread was prepared from wheat flour (82\% extraction). The baking recipe was as follows: $100 \mathrm{~g}$ flour, $0.5 \mathrm{~g}$ of active dry yeast, $1.5 \mathrm{~g}$ of sodium chloride, and 75-80 $\mathrm{mL}$ of water. All ingredients were mixed by hand for about $6 \mathrm{~min}$ to form the needed dough. The dough was left $1 \mathrm{~h}$ to have a good fermentation at $30^{\circ} \mathrm{C}$ and $85 \%$ relative humidity $(\mathrm{RH})$. After that, the dough was divided into $125 \mathrm{~g}$ pieces and was arranged on a wooden board which was covered by a fine layer of bran. The pieces of dough were left again to ferment for about $45 \mathrm{~min}$ at the previous temperature and $\mathrm{RH}$. The pieces of fermented dough were flattened to be about $20 \mathrm{~cm}$ in diameter. After the flatting process, the loaves were proof at $30{ }^{\circ} \mathrm{C}$ and $85 \% \mathrm{RH}$ for $15 \mathrm{~min}$., and then baked at $400-500{ }^{\circ} \mathrm{C}$ for $1-2 \mathrm{~min}$. the loaves were left at room temperature to cool for $2 \mathrm{~h}$.

The experimental samples were executed in the same steps of control sample, but with different levels of coffee husks $(5,10,15$, and $20 \%)$ on account of wheat flour.

\section{Loaf measurements}

The following measurements of loaf quality were taken in triplicate according to Dawoud (1989). The standing height $(\mathrm{cm})$ was measured in the center of the products. Volume was measured by rapeseed displacement after cooling for 1 hour at room temperature $\left(\sim 25^{\circ} \mathrm{C}\right)$. The products were weighed after baking and specific volume was also calculated (Volume/weight).

\section{Sensory evaluation}

All samples were presented to fifteen panelists. The samples were coded with a three-digit number and were evaluated for their sensory attributes and the scoring scheme was as follow: taste (20), flavor (15), crumb distribution (15), color of crumb (15), color of crust (15) and general appearance (20) as described by Atia (1986). The average of total score was converted to a descriptive category as follows: $90-100$ : very good 80-90: good 70-79: satisfactory less than 70 : questionable.

\section{Textural properties analysis (TPA) of bread}

Crumb texture was determined at Food Technology Research Institute, Agricultural Research Center Giza, Egypt, by a universal testing machine. (Cometech, B type, Taiwan) provided with software An Aluminum $25 \mathrm{~mm}$ diameter cylindrical probe was used in a "Texture Profile Analysis" (TPA). Double compression test to penetrate to $50 \%$ depth, at $1 \mathrm{~mm} / \mathrm{s}$ speed test. Firmness $\left(\mathrm{N} / \mathrm{cm}^{2}\right)$, gumminess $\left(\mathrm{N} / \mathrm{cm}^{2}\right)$, chewiness $(\mathrm{N} / \mathrm{cm} 2)$, cohesiveness (ratio), springiness and resilience were calculated from the TPA graphic. Both, springiness and resilience give information about the after-stress recovery capacity. But, while the former refers to retarded recovery, the latter concerns instantaneous recovery (immediately after the first compression, while the probe goes up) Texture determination carried out removing the crust, in $\left(40^{*}\right.$ $40 * 30$ minimized samples (Bourne, 2003).

\section{Biological experiment}

\section{Animals:}

Twenty-five adult male albino rats of Sprague Dawley strain (150:170 g) were purchased from the Giza Memorial Institute for Ophthalmic Research, Animal House, Ministry of Health, Giza, Egypt. The animals were adapted by keeping them in cylindrical wire cages. The feeding of animals was carried out by 
special food cups (mangers) to avoid scattering of food. Also, water was provided to the rats by glass tube projection through the wire cage. Food and water were provided and checked daily. The animals were housed under controlled normal laboratory conditions in a temperature of $20-23^{\circ} \mathrm{C}$, with a $12: 12 \mathrm{~h}$ light: Dark. After acclimatization

The rats were randomly divided into 5 equal groups according to the weight, the difference in weight between groups do not exceed $\pm 10 \mathrm{~g}$, and $\pm 5 \mathrm{~g}$ between rats in each group. The first group (G1) was a negative group which received the normal diet ad libitum (rat chow), the second group (G2) Group was a positive group which received the high fat diet (HFD). Other groups (G3, G4 and g5) were received the high fat diet and different ratios of coffee husks according to the following table:

Table (1): Composition of the experimental diets $(\mathrm{g} / \mathrm{kg})$ fed to rats.

\begin{tabular}{|c|c|c|c|c|c|}
\hline \multirow[t]{2}{*}{ Ingredients } & \multirow{2}{*}{$\begin{array}{c}\text { G } 1 \\
\text { Negative group } \\
{ }^{*} \text { ND }\end{array}$} & \multirow{2}{*}{$\begin{array}{c}\text { G2 } \\
\text { Positive group } \\
\text { HFD }\end{array}$} & G3 & G4 & G5 \\
\hline & & & \multicolumn{3}{|c|}{ High Fat Diet (HFD) + Coffee husks } \\
\hline Coffee husks & - & - & 50 & 100 & 150 \\
\hline Protein (Casein) & 200 & 200 & 200 & 200 & 200 \\
\hline Corn starch & 150 & 111 & 91 & 71 & 51 \\
\hline Sucrose & 500 & 370 & 340 & 310 & 280 \\
\hline Cellulose & 50 & 50 & 50 & 50 & 50 \\
\hline Fat (Corn oil) & 50 & 30 & 30 & 30 & 30 \\
\hline Beef tallow & - & 170 & 170 & 170 & 170 \\
\hline Mineral mixture & 35 & 42 & 42 & 42 & 42 \\
\hline Vitamin mixture & 10 & 12 & 12 & 12 & 12 \\
\hline Choline biartrate & 2 & 2 & 2 & 2 & 2 \\
\hline Cholesterol & - & 10 & 10 & 10 & 10 \\
\hline Tert-Butylhydroquinone & 0.01 & 0.04 & 0.04 & 0.04 & 0.04 \\
\hline DL-Methionine & 3 & 3 & 3 & 3 & 3 \\
\hline Total & 1000 & 1000 & 1000 & 1000 & 1000 \\
\hline Fat, \% calorie & 11.11 & 38.10 & 38.10 & 38.10 & 38.10 \\
\hline
\end{tabular}

"Composition of the normal and experimental diet (g/1000 diet) was according to the formula of Kim et al. (2009) with some modifications.

Normal and high fat diet ingredients were purchased from El-Gomhoria Company, Cairo, Egypt. Both of them were kept in refrigerator at $4^{\circ} \mathrm{C}$ until used. Obesity was induced in two months (El-Anany and Ali, 2018).

\section{Sample collection}

At the end of the two months, animals were fasted overnight and sacrificed under diethyl ether anesthesia. Blood samples were collected in a clean dry centrifuge tube from the hepatic portal vein. Tubes were separated to obtain the serum by centrifugation at $5000 \mathrm{rpm}$ for $10 \mathrm{~min}$ at room temperature and then kept in a plastic vial until analysis. Serum was used for estimation of lipid profile including triglycerides, total cholesterol, High-density lipoprotein cholesterol (HDL-cholesterol), and total lipids-by enzymatic colorimetric methods using kits (Buccolo et al., 1973; Meiattini et al., 1978; Grove, 1979; Kaplan et al., 1984), respectively. Calculation of very low-density lipoprotein cholesterol (VLDL-C) and low density lipoprotein cholesterol (LDL-cholesterol) in $\mathrm{mg} / \mathrm{dl}$ was done by using the following equation: VLDL-C = triglycerides $/ 5$, and LDL-cholesterol $=$ Total cholesterol - [HDL + VLDL)] (Lee and Nieman, 1996). The atherogenic index (AI) was calculated by using the following equation: Log [triglycerides $(\mathrm{mg} / \mathrm{dL}) / \mathrm{HDL}-\mathrm{C}(\mathrm{mg} / \mathrm{dl})]$ (Dobiásová and Frohlich, 2001).

This experiment was carried out in accordance with the guidelines of the Ethical Committee of Giza Memorial Institute for Ophthalmic Research, Animal House, Ministry of Health, Giza. Egypt.

\section{Statistical analysis}

Results were presented as mean $(\mathrm{M}) \pm$ standard deviation (SD). To assess significant difference among experimental animal groups or samples of sensory evaluation. The One-Way ANOVA analysis of samples was performed using Statistical Package for Social Sciences (SPSS version 20.0 IBM, Armonk, NY, USA), followed by Duncan's multiple range test, with a significance level set at $\mathrm{P} \leq 0.01$.

\section{RESULTS AND DISCUSSIONS}

\section{Chemical composition}

Data in Table (2) displayed the proximate chemical composition of the coffee huskss powder. The coffee husks had $10.12 \mathrm{~g} / 100 \mathrm{~g}$ crude protein, 2.56 $\mathrm{g} / 100 \mathrm{~g}$ total fat, $18.22 \mathrm{~g} / 100 \mathrm{~g}$ crude fiber, $2.7 \mathrm{~g} / 100 \mathrm{~g}$ ash, and $66.40 \mathrm{~g} / 100 \mathrm{~g}$ carbohydrates. These results were lower than that recorded by Navya and Pushpa (2013) for protein, Murthy and Naidu (2012a) for total 
fiber but were higher than that recoded by Pandey et al. (2000) and Franca and Oliveira (2009) for total lipids and total carbohydrates. In general, the chemical composition of coffee husks presents a wide range of values compared with other studies because of the differentiation in varieties, geographical location, cultivation conditions, resources in the production region, and development stage on which the coffee fruits were harvested (Mullen et al., 2013; BonillaHermosa et al., 2014).

Table (2): Chemical composition of coffee husks (g/100 g dry weight)

\begin{tabular}{lc}
\hline Parameters & M \pm SD \\
\hline Crude protein (g) & $10.12 \pm 0.82$ \\
Fat (g) & $2.56 \pm 0.051$ \\
Crude fiber (g) & $18.22 \pm 1.22$ \\
Ash (g) & $2.70 \pm 0.003$ \\
Carbohydrates ${ }^{1}$ (g) & $66.40 \pm 3.45$ \\
\hline
\end{tabular}

Each value in the table is the average of three replicates and followed by \pm standard deviation.

'Carbohydrates were calculated by difference

\section{Antioxidant Capacity Assays}

From the data displayed in Table (3), it could be noticed that DPPH test is a frequent assay used to evaluate the radical-scavenging potential of a sample including coffee husks. Usually, the high percentage or concentration of DPPH reflects the high levels of antioxidant potential in sample, that able to scavenge the free radicals in human body. The value of DPPH radical-scavenging activity of the coffee husks was recorded $53.47 \% \quad(207.25 \mathrm{mg}$ Trolox/g sample). Overall, the DPPH scavenging of the coffee husks was higher than that previously reported for husks derived from the dry and wet methods coffee processing (Ribeiro et al., 2019), but a lower 65-69\% value was detected than that recorded by Murthy and Naidu (2012b) who studied the coffee-by-products such as coffee pulp, coffee husks, and silver skin.

Data from the previous Table showed the value of ABTS, antioxidant capacity assay which recorded $2.054 \mathrm{~g}$ Trolox $/ \mathrm{g}$ sample. The cation radical of ABTS $\left(\mathrm{ABTS}^{+}\right.$) results from the loss of electron yields bluishgreen colored substance to form 2,2-azino-bis (3ethylbenzothiazoline-6-sulphonic acid) diammonium salt. In the presence of hydrogen donation atom from test article or standard Trolox, the charges are suppressed, and the solution becomes uncolored or clear. Hence The ABTS whose cationic radical form is generated by treating it with oxygenating reagents such as potassium permanganate or manganese dioxide (Miller and Rice-evans 1997). This assay is unique because it can be applied at different $\mathrm{pH}$ conditions and estimated in both organic and aqueous extracts.
Coffee husks are need to more studies about its role as an antioxidant. Andrade et al. (2011) studied the antioxidant activity of coffee husks extracts and found that the low-pressure method and extraction with ethanol were the best method to obtain the high free radical scavenging activity extract evaluated with ABTS radical $(161 \pm 3 \mathrm{mmol} \mathrm{TEAC} / \mathrm{kg})$. This value could be associated to the different coffee varieties and to different conditions of technological process. Our results about antioxidant activity measured with ABTS assay are high value to those reported in literature, which shows that the coffee by-products have an appreciable free radical scavenging activity measured with ABTS assay. Silver skin has the highest antioxidant activity (21.2 mmol Trolox $/ \mathrm{kg}$ ) followed by spent waste $(20.4 \mathrm{mmol}$ Trolox $/ \mathrm{kg})$, cherry husks (18.4 mmol Trolox $/ \mathrm{kg}$ ), and coffee pulp (15.3 mmol Trolox $/ \mathrm{kg}$ ) among the coffee byproducts (Murthy \& Naidu, 2012b).

FRAP method is another assay used to estimate the power of substance as an antioxidant. The value of FRAP antioxidant capacity assay recorded $0.832 \mathrm{~g}$ Trolox/g sample Table (3). The principle of this assay depended on the reduction of ferric $\left(\mathrm{Fe}^{3+}\right)$ form of substance to ferrous $\left(\mathrm{Fe}^{2+}\right)$ form, this assay was carried out in acidic conditions ( $\mathrm{pH}$ 3.6) to maintain the solubility of iron in ferric and ferrous form (Hagerman et al., 1998). The FRAP method is simple, fast, and efficient method which finds is applications in antioxidant estimation from body fluids, food, and plant extracts.

The result of FARP was high recorded by silva et al., (202l) who evaluated the effect of different methods (water bath and ultrasonic) and solvents (different ratios of water, and ethanol) for obtaining bioactive compounds from coffee husks and found that the wide variation between FRAP values extractions (23.38 - $2639.4 \mu$ mole Trolex /g for water bath method, and 27.62 - $3136.4 \mu$ mole Trolex $/ g$ for ultrasonic method) due to the experiment time method and kind of solvent. According to Barros et al. (2019) few phenolic compounds, such as quercetin cannot reduce $\mathrm{Fe}^{3+}$ within $30 \mathrm{~min}$. Another factor is the reduction of $\mathrm{Fe} 3+/ \mathrm{Fe} 2+$ occurs much fast in using orthophosphoric acid for extraction comparing with other solvents.

Table (3): Determinations of antioxidant capacity assays (DPPH, ABTS, and FRAB) of the coffee husks powder extract

\begin{tabular}{lc}
\hline Parameters & M \pm SD \\
\hline DPPH (\%) & $53.472 \pm 0.306$ \\
$\begin{array}{l}\text { DPPH (mg Trolox/g } \\
\text { sample) }\end{array}$ & $207.254 \pm 0.722$ \\
ABTS (g Trolox/g sample) & $2.054 \quad \pm 0.074$ \\
FRAB (g Trolox/g sample) & $0.832 \pm 0.050$
\end{tabular}

Each value in the Table is the average of three replicates and followed by \pm standard deviation. 


\section{HPLC Phenolic Compounds Profile}

From Table (4) chlorogenic acid, gallic acid, and caffeine are the main phenolic acids of coffee husks (780, 19.78 and $18.20 \mu \mathrm{g} / \mathrm{g}$, respectively). The esterification of caffeic acid with quinic acid produces chlorogenic acid, which is a soluble polyphenol (Gauthier et al., 2016). In the intestine, chlorogenic acid is hydrolyzed into caffeic acid which has a stronger antioxidant activity than chlorogenic acid, it is possible that caffeic acid plays an important role in the protective effect of chlorogenic acid against ischemiareperfusion injury (Sato et al., 2011).

Table (4): HPLC phenolic compounds profile of the coffee husks (mg/g dry weight)

\begin{tabular}{lc}
\hline Compound & Coffee husks \\
\hline Gallic acid & 19.78 \\
Protocatechuic acid & 92.23 \\
4-hydroxybenzoic acid & 6.45 \\
Vanillic acid & 2.45 \\
Syringic acid & 0.29 \\
Salicylic acid & 2.84 \\
Chlorogenic acid & 780 \\
Caffeic acid & 15.87 \\
Caffeine & 18.20 \\
p-coumaric acid & 1.89 \\
Ferulic acid & 2.2 \\
Catechin & 1.55 \\
Epicatechin & 7.94 \\
Coumarin & 1.243 \\
\hline
\end{tabular}

Coffee husks contained a moderate amount of caffeic acid, protocatechuic acid, and Epicatechin, the less amounts of phenolic compounds were observed in syringic acid, catechin and coumarin which was recorded $0.29,1.55$, and 1.243 respectively. These results were agreed with Rebollo-Hernanz et al. (2021).

Polyphenols and flavonoids are considered the main components of non-enzymatic antioxidant defense system, which have the high capacity to catch free radicals and protect body against increasing of ROS (Ferguson, 2001). Therefore, coffee husks are a good example for non-enzymatic antioxidant due to the presence of higher amounts of phenolic compounds.

\section{Sensory evaluation of balady bread}

Table (5) presents the sensory properties score and statistical analysis for balady bread which was prepared by $82 \%$ flour and different levels of coffee husks powders. From this Table, it could be observed that balady bread had no significant $(\mathrm{p}>0.01)$ effects on all sensory characteristics at level $5 \%$ coffee husks replacement compared with control balady bread characteristics except appearance, color of crust, and color of crumb but at $20 \%$ level replacement, significant $(\mathrm{p}<0.01)$ differences were observed for all characteristics compared with balady bread control. Statically, the best balady bread treatment contained $10 \%$ coffee husks powder while the balady bread containing $20 \%$ coffee husks was displayed the worst characteristics among all treatments prepared with coffee husks powder.

According to the grade, the replacement of coffee husks powder at 5 to $15 \%$ was acceptable, though $20 \%$ was unacceptable.

Table (5): Sensory evaluation of balady bread fortified with different levels of coffee husks

\begin{tabular}{|c|c|c|c|c|c|}
\hline \multirow{2}{*}{ Parameters } & \multirow{2}{*}{ Control } & \multicolumn{4}{|c|}{ Coffee husks levels } \\
\hline & & $5 \%$ & $10 \%$ & $15 \%$ & $20 \%$ \\
\hline Appearance (20) & $19.40^{\mathrm{a}} \pm 1.350$ & $18.0^{\mathrm{ab}} \pm 1.633$ & $18.0^{\mathrm{ab}} \pm 1.886$ & $17.20^{b} \pm 1.687$ & $12.00^{\mathrm{c}} \pm 1.886$ \\
\hline Color of crust (15) & $14.40^{\mathrm{a}} \pm 1.049$ & $13.80^{\mathrm{ab}} \pm 0.949$ & $13.80^{\mathrm{ab}} \pm 1.378$ & $12.75^{\mathrm{ab}} \pm 1.061$ & $10.05^{\mathrm{c}} \pm 2.127$ \\
\hline Color of crumb (15) & $14.10^{\mathrm{a}} \pm 1.049$ & $13.50^{\mathrm{ab}} \pm 1.225$ & $13.35^{\mathrm{ab}} \pm 1.107$ & $12.45^{\mathrm{ab}} \pm 1.589$ & $9.75^{\mathrm{c}} \pm 1.768$ \\
\hline Crumb distribution (15) & $14.10^{\mathrm{a}} \pm 0.775$ & $13.95^{\mathrm{a}} \pm 1.235$ & $13.75^{\mathrm{a}} \pm 1.549$ & $13.20^{\mathrm{a}} \pm 1.317$ & $9.15^{b} \pm 1.492$ \\
\hline Flavor (15) & $14.25^{\mathrm{a}} \pm 1.049$ & $14.10^{\mathrm{a}} \pm 1.061$ & $13.5^{\mathrm{a}} \pm 1.414$ & $12.3^{b} \pm 1.183$ & $9.15^{\mathrm{c}} \pm 1.492$ \\
\hline Taste (20) & $18.80^{\mathrm{a}} \pm 1.033$ & $18.60^{\mathrm{a}} \pm 1.647$ & $17.60^{\mathrm{ab}} \pm 2.06$ & $16.40^{\mathrm{b}} \pm 1.690$ & $12.20^{\mathrm{c}} \pm 1.989$ \\
\hline Overall scores (100) & $95.05^{\mathrm{a}} \pm 4.234$ & $91.95^{\mathrm{a}} \pm 5.91$ & $90.00^{\mathrm{ab}} \pm 6.57$ & $84.30^{b} \pm 5.02$ & $62.30^{\mathrm{c}} \pm 7.616$ \\
\hline Grade & Very good & Very good & Very good & Good & Questionable \\
\hline
\end{tabular}

Each value in the Table is the average of 15 panelists and followed by \pm standard deviation.

Means in the same raw bearing different superscript letters are different significantly $(\mathrm{P} \leq 0.01)$ 
Texture profile analysis of balady bread and loaf measurements

Data from Tables $(6 \&$ \&) showed that the firmness of bread samples became less hardness with increasing levels of coffee husks powder from 0 to $20 \%$. In addition, the replacement of wheat flour by different levels of coffee husks showed the same effect on firmness except for $20 \%$ coffee husks replacement. In this study, the weight of samples was not significant ( $p>0.01)$ different among bread samples. Thus, the increase in firmness was mainly related to the volume of bread samples. These results are compatible with Wanga et al. (2002) and Yamsaengsung et al., (2010), who stated that the increased bread volume is directly related to the decreased hardness values.

Cohesiveness is the ability of the material food to resist the deformation before rupturing during biting the food product. TPA results showed insignificant ( $p>0.01$ ) differences in the bread cohesiveness except at $20 \%$ coffee husks replacement, and it was decreased with increasing the level of coffee husks powder.
Gumminess and chewiness are closely related. Gumminess is the energy needed to break up a semi solid food until it is ready for ingestion, and it can be calculated by multiplication of hardness and cohesiveness. While as, Chewiness is determined by gumminess multiplied by springiness and represents the amount of energy needed to disintegrate a food for swallowing. The chewiness and gumminess values had a similar trend of hardness. These results agree with those obtained by Ibrahim (2011) who reported that both gumminess and chewiness are parameters dependent on hardness.

Springiness is defined as the ability of a sample to return to the original size through the two compressions as follow the end of the first one and the start of the second one. The results showed significant $(\mathrm{p}<0.01)$ differences among all bread treatments, but the best one was showed in bread with $5 \%$ coffee husks replacement which recorded 0.809 .

Resilience is the ratio of recoverable energy as the first compression is relieved. The resilience values had a similar trend of cohesiveness.

Table (6): Texture profile analysis parameters of balady bread fortified with different levels of coffee husks

\begin{tabular}{|c|c|c|c|c|c|}
\hline \multirow{2}{*}{ Parameters } & \multirow{2}{*}{ Control } & \multicolumn{4}{|c|}{ Coffee husks levels } \\
\hline & & $5 \%$ & $10 \%$ & $15 \%$ & $20 \%$ \\
\hline Firmness & $23.39^{\mathrm{a}} \pm 1.560$ & $8.34^{b} \pm 0.550$ & $8.040^{b} \pm 0.410$ & $7.890^{b} \pm 0.360$ & $5.540^{\mathrm{c}} \pm 0.120$ \\
\hline Cohesiveness & $0.850^{\mathrm{a}} \pm 0.030$ & $0.813^{\mathrm{a}} \pm 0.015$ & $0.780^{\mathrm{a}} \pm 0.020$ & $0.760^{\mathrm{a}} \pm 0.020$ & $0.660^{\mathrm{b}} \pm 0.060$ \\
\hline Gumminess & $19.882^{\mathrm{a}} \pm 1.230$ & $6.780^{b} \pm 0.590$ & $6.271^{\mathrm{b}} \pm 0.360$ & $5.996^{b} \pm 0.120$ & $3.656^{\mathrm{c}} \pm 0.420$ \\
\hline Springiness & $0.943^{\mathrm{a}} \pm 0.045$ & $0.890^{\mathrm{ab}} \pm 0.030$ & $0.820^{b c} \pm 0.030$ & $0.773^{\mathrm{cd}} \pm 0.015$ & $0.730^{\mathrm{d}} \pm 0.020$ \\
\hline Chewiness & $18.740^{\mathrm{a}} \pm 1.860$ & $6.035^{b} \pm 0.450$ & $5.142^{b} \pm 0.530$ & $4.635^{b} \pm 0.140$ & $2.669^{c} \pm 0.260$ \\
\hline Resilience & $0.790^{\mathrm{a}} \pm 0.030$ & $0.780^{\mathrm{a}} \pm 0.020$ & $0.780^{\mathrm{a}} \pm 0.020$ & $0.760^{\mathrm{a}} \pm 0.020$ & $0.500^{b} \pm 0.080$ \\
\hline
\end{tabular}

Each value in the Table is the average of three replicates and followed by \pm standard deviation.

Means in the same raw bearing different superscript letters are different significantly $(\mathrm{P} \leq 0.01)$

Table (7): Loaf measurements of balady bread fortified with different levels of coffee husks powders.

\begin{tabular}{|c|c|c|c|c|c|}
\hline \multirow{2}{*}{ Parameters } & \multirow{2}{*}{ Control } & \multicolumn{4}{|c|}{ Coffee husks levels } \\
\hline & & $5 \%$ & $10 \%$ & $15 \%$ & $20 \%$ \\
\hline Weight (g) & $104^{\mathrm{a}} \pm 2.300$ & $103.6^{\mathrm{a}} \pm 1.960$ & $103.1^{\mathrm{a}} \pm 1.890$ & $102.2^{\mathrm{a}} \pm 1.770$ & $101^{\mathrm{a}} \pm 1.650$ \\
\hline Volume (cc) & $201^{\mathrm{a}} \pm 1.320$ & $182^{\mathrm{d}} \pm 1.330$ & $186^{\mathrm{c}} \pm 1.260$ & $190^{b} \pm 1.530$ & $193^{\mathrm{b}} \pm 1.020$ \\
\hline Specific volume (cc/g) & $1.932^{\mathrm{a}} \pm 0.030$ & $1.756^{\mathrm{b}} \pm 0.025$ & $1.804^{\mathrm{b}} \pm 0.019$ & $1.859^{b} \pm 0.019$ & $1.910^{\mathrm{c}} \pm 0.014$ \\
\hline Height (cm) & $5.4^{\mathrm{a}} \pm 0.220$ & $5.1^{\mathrm{ab}} \pm 0.410$ & $4.9^{\mathrm{ab}} \pm 0.610$ & $4.7^{\mathrm{ab}} \pm 0.120$ & $4.3^{b} \pm 0.320$ \\
\hline Loaf diameter $(\mathrm{cm})$ & $15.3^{\mathrm{a}} \pm 0.990$ & $14.5^{\mathrm{a}} \pm 1.120$ & $13.5^{\mathrm{a}} \pm 1.060$ & $13^{\mathrm{a}} \pm 1.200$ & $12.6^{\mathrm{a}} \pm 1.510$ \\
\hline
\end{tabular}

Each value in the Table is the average of three replicates and followed by \pm standard deviation.

Means in the same raw bearing different superscript letters are different significantly $(\mathrm{P} \leq 0.01)$ 
Serum lipid profile of rats administered experimental diets

The effect of coffee husks powder substitutions for 8 weeks on serum total lipids, triglycerides, total cholesterol (T-C), high density lipoprotein cholesterol (HDL-C), low density lipoprotein cholesterol (LDL-C), and very low density lipoprotein cholesterol (VLDL-C) concentrations in rats fed on HDF is shown in Table (8). All lipid profile parameters were significantly increased $(\mathrm{p} \leq 0.01)$ in rats, which were fed on the HDF compared with the control (-) rats group fed on basal diet except, high density lipoprotein cholesterol (HDLC) parameter. The coffee husks powder level at $15 \%$ showed a significant improvement in all lipids profile parameters followed by $10 \%$, and $5 \%$, except total lipids which have the same effect at 10 or $15 \%$ coffee husks replacement. The high density lipoprotein cholesterol (HDL- C) concentration of rats fed on HFD was sharply decreased by $41.18 \%$ as compared with the control group.

In general, the administration of various levels of coffee husks to rats fed on HFD significantly improved all lipid parameters $(\mathrm{P} \leq 0.01)$ by decreasing serum total lipids, total cholesterol, triglycerides, low density lipoprotein cholesterol (LDL-C), very low density lipoprotein cholesterol (VLDL-C), and increasing serum high density lipoprotein cholesterol (HDL-C).

The comparison between the rats fed on the HFD and rats fed on the HFD containing $15 \%$ coffee husks showed that values of the total lipids, triglycerides, total cholesterol, low density lipoprotein cholesterol (LDL-C), and very low density lipoprotein cholesterol (VLDL-C) were enhanced by $9.57,29.14$, $35.41,36.63$, and $29.14 \%$, respectively. It is clear that the higher level of coffee husks at $15 \%$ has improved the lipid parameters more than the level at 5\%.
The incorporation of different levels of coffee husks into the HFD caused a significant reduction ( $P$ $<0.01)$ in the Atherogenic index value. The value of Atherogenic index of rats administered with HFD at 5, 10 , and $15 \%$ coffee husks recorded $0.606,0.510$, and 0.411 , respectively. The Atherogenic index from the previous values was lower than the Atherogenic index value of rats fed on HFD.

The obtained results indicated the coffee husks served an important role in reducing serum lipids (Table 8). The coffee husks powder is a complex mixture contains several bioactive compounds including caffeine, polyphenols, and diterpenes that affect serum lipids (Hoseini et al., 2021). After two months of coffee husks powder intake, caffeine from the husks elevated the breakdown of fat cells and fat oxidation in vivo through lipolysis in fat cells and the release of catecholamines, thereby inhibiting weight gain and body fat accumulation in animals (Zheng et al., 2004; Lee et al., 2017). Caffeine has been reported to facilitate the release of norepinephrine from sympathetic nervous system resulting in accelerating the consumption of energy and loss of body fats (Westerterp-Plantenga et al., 2006; and Acheson et al., 2004). Same results were observed by Shimoda et al. (2006) who studied the effect of green coffee bean extract on fat accumulation and body weight gain in mice and found that caffeine, chlorogenic acid and other polyphenolic compounds act as a synergist agent to suppress body weight gain and visceral fat accumulation in mice. The explanation of chlorogenic mechanism depends on inhibiting the hepatic Peroxisome Proliferators'-Activated Receptor $\gamma$ $(\operatorname{PPAR} \gamma)$, which promotes the fatty acids uptake into liver cells (Naveed, et al., 2018).

Table (8): Effect of different coffee husks powder levels on serum total lipids profile of hyperlipidemic rats.

\begin{tabular}{|c|c|c|c|c|c|}
\hline \multirow{2}{*}{ Parameters } & \multirow{2}{*}{$\begin{array}{c}\text { G1 } \\
\text { Control } \\
(-)\end{array}$} & \multirow{2}{*}{$\begin{array}{c}\text { G2 } \\
\text { Control } \\
(+)\end{array}$} & \multicolumn{3}{|c|}{ Coffee husks levels } \\
\hline & & & G3 $(5 \%)$ & G4 (10 \%) & G5 (15\%) \\
\hline Total lipids (md/dl) & $277^{\mathrm{a}} \pm 3.29$ & $355^{\mathrm{d}} \pm 6.36$ & $340^{c} \pm 3.65$ & $332^{\mathrm{bc}} \pm 5.20$ & $321^{\mathrm{b}} \pm 2.92$ \\
\hline Triglycerides (md/dl) & $89.51^{\mathrm{a}} \pm 2.45$ & $172.64^{\mathrm{e}} \pm 2.13$ & $153.22^{\mathrm{d}} \pm 2.68$ & $131.18^{\mathrm{c}} \pm 3.35$ & $122.33^{\mathrm{b}} \pm 2.78$ \\
\hline Total cholesterol (md/dl) & $136.23^{\mathrm{a}} \pm 2.88$ & $293.15^{\mathrm{e}} \pm 2.32$ & $244.89^{d} \pm 3.45$ & $207.45^{\mathrm{c}} \pm 3.36$ & $189.33^{\mathrm{b}} \pm 3.76$ \\
\hline HDL-cholesterol (md/dl) & $55.36^{\mathrm{a}} \pm 0.85$ & $32.56^{\mathrm{e}} \pm 0.93$ & $37.89^{\mathrm{d}} \pm 0.72$ & $40.54^{\mathrm{c}} \pm 0.88$ & $47.46^{\mathrm{b}} \pm 0.29$ \\
\hline LDL-cholesterol (md/dl) & $62.97^{\mathrm{a}} \pm 3.45$ & $226.07^{\mathrm{e}} \pm 1.89$ & $176.36^{\mathrm{d}} \pm 2.88$ & $140.68^{c} \pm 3.45$ & $117.41^{b} \pm 3.33$ \\
\hline $\begin{array}{l}\text { VLDL- cholesterol } \\
(\mathrm{md} / \mathrm{dl})\end{array}$ & $17.90^{\mathrm{a}} \pm 0.49$ & $34.52^{\mathrm{e}} \pm 0.42$ & $30.64^{\mathrm{d}} \pm 0.53$ & $26.23^{c} \pm 0.67$ & $24.46^{\mathrm{b}} \pm 0.55$ \\
\hline Atherogenic index & $0.206^{\mathrm{a}} \pm 0.005$ & $0.724^{\mathrm{e}} \pm 0.007$ & $0.606^{\mathrm{d}} \pm 0.001$ & $0.510^{\mathrm{c}} \pm 0.002$ & $0.411^{\mathrm{b}} \pm 0.007$ \\
\hline
\end{tabular}

Each value in the Table is the average of 5 rats from each group and followed by \pm standard deviation.

Means in the same raw bearing different superscript letters are different significantly $(\mathrm{P} \leq 0.01)$ 


\section{CONCLUSION}

This study aimed to the utilization of coffee husks as a by-product in the preparing of balady bread loaves. The different levels of Coffee husks had significant effects on the textural, physical, and sensory attributes of balady bread loaves. Panelists decided the best levels added to the bread 5 to $15 \%$ of coffee husks replacement. On the other side, coffee husks have a therapeutic role in reduction lipid profile (total lipids, triglycerides, total cholesterol, low density lipoprotein cholesterol, and very low density lipoprotein cholesterol) and raising high density lipoprotein cholesterol. These balady bread loaves are an excellent option for diabetic and hyperlipidemic patients because they are rich in fiber, total phenols, and antioxidants. Coffee husks are still need more research about the effect of coffee husks as antinutritional factors and how to use them in other different functional products such as cakes, beverages, pizza, and bakery products.

\section{REFERENCES}

AOAC (2000). Official Methods of Analysis. The Association of Official Analytical Chemists, $17^{\text {th }}$ Ed. Washington, MD, USA.

Acheson, K.J., G. Gremaud, I. Meirim, F. Montigon, Y. Krebs, L.B. Fay, L.J. Gay, P.Schneiter, C.Schindler and L. Tappy (2004). Metabolic effects of caffeine in humansLipid oxidation or futile cycling. Am. J. Clin. Nutr., 79(1): 40-46.

Akillioglu, H.G. and S. Karakaya (2010). Changes in total phenols, total flavonoids, and antioxidant activities of common beans and pinto beans after soaking, cooking, and in vitro digestion process. Food Sci. Biotechnol., 19(3): 633-639.

Andrade, K. S., R. T. Goncalvez, M. Maraschin, R. M. Ribeiro-do-Valle, J. Martínez and S.R.S. Ferreira (2011). Supercritical fluid extraction from spent coffee grounds and coffee huskss-Antioxidant activity and effect of operational variables on extract composition. Talanta, 88(15): 544-552.

Atia, A.A. (1986). Physical and chemical studies on the staling of some Egyptian bread. Ph.D. in Food Science, Cairo Univ., Egypt.

Barros, H.D.F.Q., A.M. Baseggio , C.F.F. Angolini, G.M. Pastore, C.B.B. Cazarin and M.R. Marostica-Junior (2019). Influence of different types of acids and $\mathrm{pH}$ in the recovery of bioactive compounds in Jabuticaba peel (Plinia cauliflora). Food Res. Int., 124: 16-26.

Bekalo, S.A. and H.W. Reinhardt (2010). Fibers of coffee husks and hulls for the production of particleboard. Materials and Structures, 43:1049-1060.

Benzie, I.F.F. and J.J. Strain (1996). The ferric reducing ability of plasma (FRAP) as a measure of "antioxidant power" - the FRAP assay. Analytical Biochemistry, 239:70-76.

Berlitz, H.-D., W. Grosch and P. Schieberle (2009). Food chemistry $\left(4^{\text {th }}\right.$ ed. $)$. Springer-Verlag. https://doi.org/10.1007/978-3-540-69934-7

Bidel, S. and J. Tuomilehto (2013). The emerging health benefits of coffee with an emphasis on type 2 diabetes and cardiovascular disease. Eur. Endocrinol., 9(2): 99-106.

Bonilla-Hermosa, V.A., W.F. Duarte and R.F. Schwan (2014). Utilization of coffee by-products obtained from semi-washed process for production of value-added compounds. Bioresour. Technol., 166: 142-150.

Bourne, M.C. (2003). Food Texture and viscosity Concept and measurement. Elsevier Press New York/London.

Buccolo, G. and David, H. (1973). Quantitative determination of serum triglycerides by use of enzimes. Clin. Chem., 19(5): 476-482.

Castaldo, L., G. Graziani, A. Gaspari, L. Izzo, C. Luz, J. Mañes, M. Rubino, G. Meca and A. Ritieni, (2018). Study of the Chemical Components, Bioactivity and Antifungal Properties of the Coffee Husks. Journal of Food Research, 7(4): 43-54.

Dawoud, F.M. (1989). High Fiber Bread for the Management of Diabetes - Product Development, Physiological Testing and Sensory Evaluation. Ph.D. Food and Nutrition Science Dept. Food Sci. Division, Kings collage London - University of London.

Dobiásová, M. and J. Frohlich (2001). The plasma parameter log (TG/HDLC) as an atherogenic index- correlation with lipoprotein particle size and esterification rate in apo Blipoprotein depleted plasma (FER (HDL). Clin. Biochem., 34(7): 583-588.

Eissa, H.A., A.S. Hussein and B.E. Mostafa (2007). Rheological properties and quality evaluation of Egyptian balady bread and biscuits supplemented with flours of ungerminated and germinated legume seeds or mushroom. Pol. J. Food Nutr. Sci., 57(4): 487-496.

El-Ananya, A.M. and R.F.M. Ali (2018). Hypolipidemic effect of coffee silver skin in rats fed a high-fat diet. Food Science and Human Wellness, 7: 252-259.

Ferguson, L.R. (2001). Role of plant polyphenols in genomic stability. Mutat. Res., 475 (1-2): 89-111.

Franca, A.S. and L.S. Oliveira (2009). Agricultural Wastes, Agriculture Issues and Policies. Nova Publishers, New York.

Gauthier, L., M.N. Bonnin-Verdal, G. Marchegay, L. Pinson-Gadais, C. Ducos, F. Richard-Forget and V. Atanasova-Penichon (2016). Fungal biotransformation of chlorogenic and caffeic acids by Fusarium graminearumnew insights in the contribution of phenolic acids to resistance to deoxynivalenol 
accumulation in cereals. Int. J. Food Microbiol., 221: 61-68.

Gouveia, S. and P.C. Castilho (2011). Antioxidant potential of Artemisia argentea L'Hér alcoholic extract and its relationship with the phenolic composition. Food Research International, 44(6): 1620-1631.

Grove, T. H. (1979). Effect of reagent $\mathrm{pH}$ on Determination of HDL Cholesterol by precipitation with Sodium Phosphotungstate-magnesium. Clin. Chem., 25: 560 .

Hagerman, A.E., K.M. Riedl, G.A. Jones, K.N. Sovik, N.T. Ritchard, P.W. Hartzfeld, and T.L. Riechel (1998). High molecular weight plant polyphenolics (Tannins) as biological antioxidants. J. Agric. Food Chem., 46(5): 1887-1892.

Heeger, A., A. Kosinska-Cagnazzo, E. Cantergiani, and W. Andlauer (2017). Bioactive of coffee cherry pulp and its utilization for production of Cascara beverage. Food Chem., 221: 969-975.

Hoseini, M., S. Cocco, C. Casucci, V. Cardelli and G. Corti (2021). Coffee by-products derived resources. A review). Biomass and Bioenergy, 148: 1-10.

Ibrahim, M.A.K. (2011) Chemical and biological studies on some bakery products. Ph.D. Thesis, Food Science Dep. Fac. Agric., Moshtohor, Banha Univ., Egypt.

ICO (2020) Coffee Trade Statistics Infographic. Int. Coffee https://www.ico.org/trade_statistics.asp

Organ.

Kaplan, A., et al. (1984). Lipids. Clin Chem The C.V. Mosby Co. St Louis. Toronto. Princeton. 918-919.

Kim, S-H., S-O.Yang, H-S. Kim, Y. Kim, T. Park and H-K. Choi (2009). ${ }^{1} \mathrm{H}$-nuclear magnetic resonance spectroscopy-based metabolic assessment in a rat model of obesity induced by a high-fat diet. Anal. Bioanal. Chem., 395: 1117-1124.

Lee, J., H.Y. Kim and J. Kim (2017). Coffee Consumption and the Risk of Obesity in Korean Women. Nutrients, 9(12): 1-12.

Lee, R.D. and D.C. Nieman (1996). Nutrition Assessment. 2nd ed. Mosby-Yearbook, St Louis, Mo.pp. 195-197.

Meiattini, F., et al. (1978). The 4-hydroxybenzoate/4aminophenazone Chromogenic System.Clin. Chem., 24 (12): 2161-2165.

Meng, S., J. Cao, Q. Feng, J. Peng and Y. Hu (2013). Roles of chlorogenic acid on regulating glucose and lipids metabolism- A review. Evid. Based Complement. Alternat. Med., 2013: 1-11.

Mennini, T. (2013). Food waste and byproducts. A sustainable source of antioxidants. Nutra.foods, 12: 30-31.

Miller, N.J. and C.A. Rice-Evans (1997). Factors influencing the antioxidant activity determined by the $\mathrm{ABTS}^{+}$radical cation assay. Free Radic. Res., 26(3): 195-199.

Mullen, W., B. Nemzer, A. Stalmach, S. Ali and E. Combet (2013). Polyphenolic and Hydroxycinnamate Contents of Whole Coffee Fruits from China, India, and Mexico. J. Agric. Food Chem., 61(22): 5298-5309.

Murthy, P.S. and M.M. Naidu (2012a). Sustainable management of coffee industry by-products and value addition-A review. Resources, Conservation and Recycling, 66: 45- 58.

Murthy, P. S. and M.M. Naidu (2012b). Recovery of phenolic antioxidants and functional compounds from coffee industry byproducts. Food and Bioprocess Technology, 5: 897-903.

Naveed, M., V. Hejazi, M. Abbas, A.A. Kamboh, G.J. Khan, M. Shumzaid, F. Ahmad, D.Babazadeh, X. FangFang, F. ModarresiGhazani, L. WenHua and Z. XiaoHui (2018). Chlorogenic acid (CGA)- A pharmacological review and call for further research. Biomedicine \& Pharmacotherapy, 97: 67-74.

Navya, P.N. and S.M. Pushpa (2013). Production, statistical optimization, and application of endoglucanase from Rhizopus stolonifer utilizing coffee husks. Bioprocess Biosyst. Eng., 36: 1115-1123.

Pan,M-H., Y-C. Tung, G. Yang, C. Li and C-T. Ho (2016). Molecular mechanisms of the antiobesity effect of bioactive compounds in tea and coffee. Food and nutrition, 7: 44814491.

Pandey, A., C.R. Soccol, P. Nigam, D. Brand, R. Mohan and S. Roussos (2000). Biotechnological potential of coffee pulp and coffee husks for bioprocesses. Biochemical Engineering Journal, 6(2): 153-162.

Rebollo-Hernanz, M., S. Cañas, D. Taladrid, V. Benítez, B. Bartolomé, Y. Aguilera and M. Cabrejas (2021). Revalorization of Coffee Husks- Modeling and Optimizing the Green Sustainable Extraction of Phenolic Compounds.Foods, 10(3): 1-23.

Ribeiro, E.F., D.M.M. Luzia and N. Jorge (2019). Antioxidant compounds extraction from coffee huskss- the influence of solvent type and ultrasound exposure time. Acta Scientiarum Technology, 41: 375-381.

Sato, Y., S.I. tagaki, T. Kurokawa, J. Ogura, M. Kobayashi, T. Hirano and et al. (2011). In vitro and in vivo antioxidant properties of chlorogenic acid and caffeic acid. International Journal of Pharmaceutics, 403(1-2): 136-138.

Shimoda, H., E. Seki and M. Aitani (2006). Inhibitory effect of green coffee bean extract on fat accumulation and body weight gain in mice. BMC Complementary and Alternative Medicine, 6: 1-9. 
Silva, M.d.O., J.N.B. Honfoga, L.L. De Medeiros, M.S. Madruga and T.K.A. Bezerra (2021). Obtaining bioactive compounds from the coffee husks (Coffea arabica L.) Using Different Extraction Methods. Molecules, 26(1): 46.

WHO (2020). Obesity and overweight. Available online- https-//www.who.int/news-room/ fact-sheets/detail/obesity-and-overweight (accessed on 1 April 2020).

Wanga, J., C. M. Rosella and C. B. Barbera (2002). Effect of the addition of different fibers on wheat dough performance and bread quality. Food Chemistry, 79(2): 221-226.
Westerterp-Plantenga, M., K. Diepvens, A.M. Joosen, S. Berube-Parent and A. Tremblay (2006). Metabolic effects of spices, teas, and caffeine. Physiology Behavior, 89(1): 8591.

Yamsaengsung, R., R. Schoenlechner and E. Berghofer (2010). The effects of chickpea on the functional properties of white and whole wheat bread. International Journal of Food Science and Technology, 45(3): 610-620.

Zheng, G., K.Sayama, T. Okubo, L.R. Juneja and I. Oguni (2004). Anti-obesity effects of three major components of green tea, catechins, caffeine and theanine, in mice. In Vivo, 18(1): 55-62.

\section{الاستفادة من قشور القهوة لتحضير منتجات وظيفية}

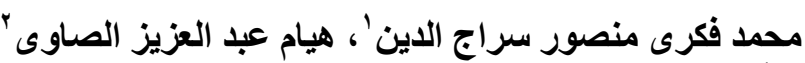

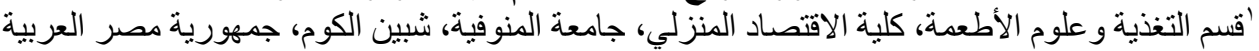

"آسم الأغذية الخاصة والتغنية، معهد بحوث تكنولو جيا الأغذية، مركز البحوث الزراعية، وزارة الزر اعة واستصلاح الأراضي، الجيزة، مصر

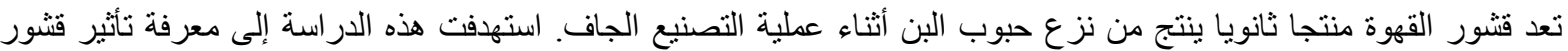

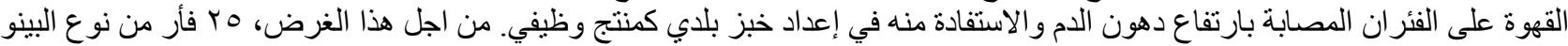

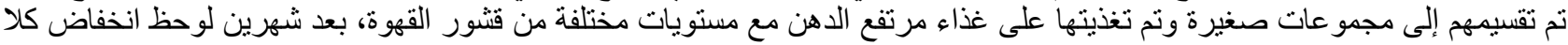

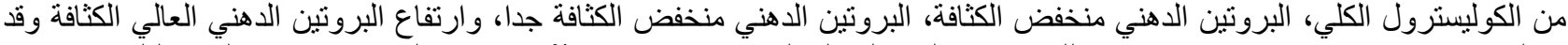

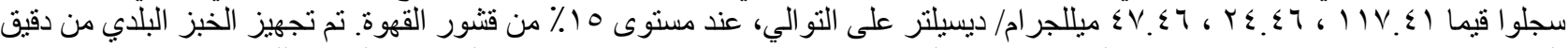

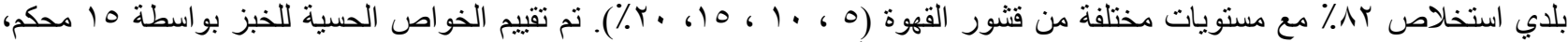

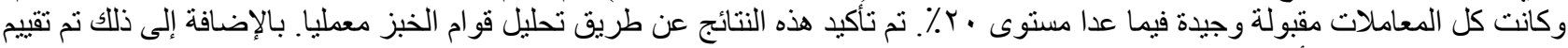

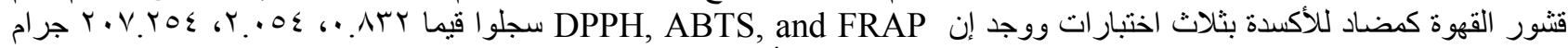

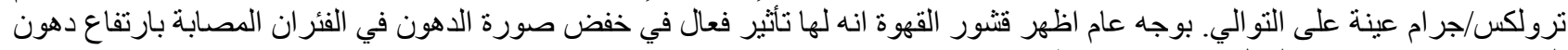

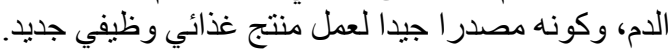

الكلمات الدالة: قشور القهوة، مضادات الأكسدة، الخبز، الأحماض الفينولية 